\title{
A person in a closed environment as a psychological problem
}

\author{
YuliyaV. Klochko \\ Barnaul Law Institute of Russian Ministry of Internal Affairs, Barnaul, Russia
}

\begin{abstract}
This article addresses an ethically weighted problem which is related to modern psychology: when a person lives in a closed environment. A new approach to solving this problem is being examined. It is based on the finding of substantial new functional aspects of the cognitive processes of making and losing meaning. The study of this sub-discipline started with O.K. Tikhomirov's theory of thinking. The phenomenon of "adaptability to changes in lifestyle" is being analyzed. The substantial characteristics of the notion of a "closed environment" as well as the psychological manifestations which appear when one is forced to live in a closed environment or choses to live in one of his or her own volition are being revealed. According to the author, the new approach will allow us to come closer to understanding and being able to explain the psychological mechanisms of the mental upheaval which prisoners in solitary confinement experience.
\end{abstract}

Key words: meaning-making, rethinking, meaning-losing, open system, closed environment, world image, lifestyle.

Following the results of research work carried out in O.K. Tikhomirov's scientific school to study the thinking patterns at play in real-life activity, the problems of meaning-making and the possibility of future rethinking or meaning-losing got a new impulse. While thinking is a mental process, it is difficult to find its axiological dynamics, which determine its selectivity and orientation. In real-life activity, the function of thinking does not lead to a problem's solution, especially to the problems raised by someone else, as defined in this or that way and somehow presented to a person in a ready-made finished form. So what is the functional role of thinking in the real-life activity of a person?

When the materials from L.S. Vygotsky's personal archive became accessible in 2008, it turned out that the author of the cultural and historical approach has analyzed this problem. In one of his records, he states: "as soon as we remove the thinking from our lives (from dynamics) - taken as a mental but not a psychological notion - we will have closed off any way of finding and explaining its main characteristic: to determine lifestyle and behavior" (Zavershneva, 2008, p. 129). Based on the results of the studies of the psychological specifics of the regulation of thinking in real-life activity, O.M. Krasnoryadtseva concluded that the main function of thinking consists of the exposure of the conflict between the image of 
the world and the lifestyle of a person, and the determination of ways to resolve it (Krasnoryadtseva, 1997). Meanwhile, thinking fulfills an important function: it mediates the processes of the change of lifestyles and the image of the world by providing balance between them, although it gets altered anyway due to the conflict between how a person understands the world and what (and how) he does in the world - this is the source of a person's psychological self-movement, or internal changes.

In our studies it was stated that people have a different degree of readiness to lifestyle changes (Klochko, 2002). Meanwhile, the readiness itself was used as a systematic psychological construct which characterizes the person's ability to accept inevitability and the irreversibility of losses in life and to rearrange their lifestyles under conditions of independent choice or through external regulation. This also involves some efforts (including thinking) which should be applied to maintain self-identity despite conditions where the axiological dimensions of life space change, as a condition for helping a person adapt to a new life style.

In our study, the participants were students who had entered a military educational institution, i.e. a closed institution where the lifestyles of residents are regulated in a way that sharply limits the usual system of axiological regulation and demands the formation of a new one. Thus, the problems of meaning-making and rethinking have proved to be the focus of the study. For a student who fails to cope with regulations, complicated problems appear, such as meaning-losing. Problems appear if the new lifestyle, which is highly regulated from the outside, is placed in the center of a negative emotional state, and the problem is revealed in the form of disappointment in personal choices, the denial of dreams, and the destruction of the future plans which were established before the individual entered the military academy. Since a meaning dimension emerges to take part in the processes of meaning-making, the inner personal world may become either broader or narrower, following the external regulations which limit "the space of free actions" (K. Levin) and result in an "existential vacuum", or meaning-losing. Currently, the environments that feature such a restricting regulation are more and more frequently called closed.

Enrollment in a closed educational institution very often means that the students find themselves involved in a particularly stressful situation. Such emotions are more typical for the students who did not have a strong intention to enter the closed educational institution and had external reasons instead, for example following a friend, or accepting advice from someone who knows little about the difficulties of staying in such an institution despite the fact that it provides few other opportunities than to one day become a policeman.

The results of our study prove the existence of the dynamic characteristics revealed in the indexes of the "rigidity-flexibility" continuum, within the structure of readiness to the lifestyle change in young people who have chosen professions which demand special working conditions. At the same time the reflexive abilities of a person are revealed in the indexes of the "internality-externality" continuum. Attempts to establish that a dependence correlation exists between these two indexes have revealed that there is no definite direct dependence between them. Qualitative analysis exemplifies a number of typical specific moments in the continuum-like "rigidity-flexibility" and "internality-externality" scales when 
analyzing the indexes of psychological maturity and the extreme meanings of students who experience the typical process of adaptation to a lifestyle which is regulated by the conditions that are present when studying in the closed educational institution.

According to O.K. Tikhomirov's opinion, the specification of ideas about the psyche should be carried out in the context of "ideas about the psyche as the formation of new reality" (Tikhomirov, 1992, p. 59); it's possible to give a different explanation to many psychological phenomena which appear when a person adapts to a new, strictly regulated lifestyle in a closed environment. The established psychological tradition turns the process of adapting to a new lifestyle into an analysis of "the sum total of the adaptive reactions of the organism". It stresses the fact that complete adaptation comes when the new conditions in which the students find themselves "become habitual" (Khoroshavina, 1996).

In the new paradigm, the process which has been traditionally called "adaptation" appears to be really complicated. It shows that readiness to accept a lifestyle change is systematic and extra-situational, and has a personally-dependant description presenting specific occurrences and directions for its rearrangement as a human being seen as "an open system" under the influence of external (not depending on a person) and internal (self-determination) factors.

It is known that Tikhomirov's idea about the psyche forming its own reality is considered the basis for the theory of psychological systems (TPS). Meanwhile, a person and a life space created by him/her are examined together: a person goes on digging into the world, the psyche is not discrete, it is continuous and provides remote action, i.e. it connects with something in the world that has meaning, sense and value to the individual. In the TPS the person is understood as a psychological system that is open to the cultural, natural and social world and their support - to the self (Klochko, 1996). The psyche transforms an impersonal, indifferent, "environment" which exists unto itself into a multi-dimensional animated space of life where a person can act and understand the meaning and value of his/her actions (Galazhinsky, Klochko, 2011; Galazhinsky, Klochko, 2012). That is why one's lifestyle cannot be separated from the process of the formation of one's psychological reality, the multi-dimensional human world: its transformation is a consequence of the lifestyle change.

It is necessary to notice that "the meaning to act without tendency about the subject that has meaning is as absurd as the tendency to act without meaning" (Klochko, 2008, p. 37). According to the TPS, emotions and attitudes are systemic dynamic formations ("complexes") which characterize the specifics of rearrangement of human life under the influence of the new demands of the environment. How can we present numerous psychological interactions which accompany the rearrangement of a person - an open psychological system who has to get used to a new lifestyle?

The mindsets which have been formed earlier manifest themselves as a readiness to act in a certain way in the established conceptual reality. Facing new realities which are not yet fully understood and are presented as material rather than axiological entities, these mindsets lose their sense. At the same time they cannot be blocked, even if they are obviously inappropriate for the new life conditions. Meanwhile, the well-oriented activity appears to be an emotional activity that has 
lost its intentionality. At the phenomenological level the wide spectrum of emotional expression (from apathy to exaltation) is presented in the form of aggression, anxiety, a feeling of isolation, the meaninglessness of life and neuroses.

Some meaning is preserved and retained until the end, some are reflected differently (the purpose of thinking is to think to rethink), and some are lost. However, when relations with the world become limited and are influenced by external regulation (in close system such as a jail, military service, enrollment in a military university, exile, forced emigration, etc.), an all-powerful emotional background appears. Emotional-attitudinal complexes connote what could be called communicating vessels. When a person acts in habitual conceptual reality, the emotional and semantic component of his/her activity is in the sidelines, and the attitudinal component is presented by an emerging activity. When the attitudes do not correspond to the new reality and lose sense, the emotional component of activity takes the leading position; part of it starts the procedures of meaning-making (the formation of a new conceptual reality), and another part manifests itself in the form of emotional activity directed to nowhere. The weaker the self-organization of a person as an open psychological system is, the more destructive the emotional activity which asserts itself becomes.

As an example, we have to examine the history and origin of the so-called "temporal neuroses". This notion was introduced by S.A. Kravchenko in 2009. It denotes disadaptative states and the attempts of a person to live primarily in only one time period: either the past, present or future or to feel a state of timelessness where a feeling of detachment dominates (Kravchenko, 2009). According to S.A. Kravchenko, such a neurosis is widespread and is exemplified by the desire of some women to be "forever young", while the present reality and especially old age to come is rejected. At the same time, in the case of males, the same neurosis manifests itself as a desire to live in the future, while present or past goals and plans become sacrificed in the name of the future. In adulthood the temporal neurosis often manifests itself by the shift of the focus of consciousness to the past. This state leads to inability of a person to study something new and even to perceive innovations positively; the values of the past replace everything.

The notion of temporal neurosis can be analyzed in the context of the TPS. First of all, the notion of "temporality" itself is frequently used to denote the temporal nature of phenomena which were produced by the dynamics of their own action as opposed to those temporal characteristics which are determined by the relation of the action of the given phenomenon in its historical, biological, physical, etc. temporal coordinates. In the TPS a person is considered as an open self-developing system. Thus the temporal manifestations are considered to be something in which the dynamics of human existence are reflected. The dynamics are accompanied by the transformation of the axiological dimensions of life space which occur as a result of self-development under the influence of external factors which influence the effectiveness of self-realization (Borodina, 2008).

Using the example of conscripts, V.N. Borodina examined the temporal manifestations of the effect of the extreme rearrangement of the established lifestyle. She noticed that "the closing" of a person who initially was an open self-developing system when s/he starts adapting to the highly regulated (from outside) lifestyle leads to the appearance of temporal manifestations apparently connected with the 
deformation of the axiological content of the image of the world and the conscripts' lifestyle (Borodina, 2008). From this description, it follows that temporal manifestations are the natural results of the process of the resolution of the conflict between the necessity to accept a new lifestyle and the preservation of the axiological content of the world image which was formed during the prior lifestyle.

The results of the study show that the specifics of temporal manifestations are closely connected to the individuality and personal traits, such as rigidity/flexibility, locus of control (internality/externality), and other axiological, motivational and self-actualizing characteristics. The regularities that are specific to the different stages of compulsory military service are found in the emergence of temporal manifestation. They are presented by diverse orientations of a person towards one time period (past, present, or future), the emergence of the effects of "time idealization", the "derealization of the present", time "condensation", "slowing-down" or "speeding-up". It is necessary to notice that these manifestations are referred to the parameters of temporal neurosis.

Developing the notion of a "closed space-temporal system", O.M. Pisarev states that staying in places where freedom is deprived is accompanied by a particular emotional background, such as latent anxiety, negative emotions, a feeling that there is a lack of safety, impulsivity, inner conflict, fatigue, and impatience (Pisarev, 2009).

I.S. Khudyakova uses the notion "closed environment of correctional institution" which denotes local space based on the system of regulations which highly limit the exchange/connection of an open system, i.e. a person and the external world (Khudyakova, 2013). She names the levels and the content of experiencing loneliness in environments with different degrees of closeness which are determined by the regulations of the correctional institution. In result, a strong sense of loneliness prompted by the conditions of a closed environment is accompanied by the development of a number of temporal manifestations (the feeling of timelessness, "fixedness" of a person in one of the time periods - past, present or future).

L.A. Rassudova mentioned that the students of closed-type institutions experience the same manifestations. She believes that they appear as a result of response to factors that threaten to damage the self (the "I") as an entity and present one of the forms of destructive psychological defense (Rassudova, 2013).

We consider the forced extreme alteration of the lifestyle caused by the adaptation of a person in a "close" environment is in fact the deformation of the whole chronotopic organization of a person as a very complicated space-temporal system. In particular, for a while, life-sustaining activity loses its meaning- orienting points. Rethinking (the solution of the semantic problem) is the mechanism of "the chronotope reconstruction" and meaning-losing is a sort of payment for the imperfection of this mechanism.

In the framework of the problem of the "space-temporal organization of the life world of a person", Ye.V. Nekrasova (2005) used a transspective analysis and showed that forcing a person to do something against his/her will (imprisonment, exile, deportation, deprivation, etc.) leads to the deformation of his/her life world. This deformation takes the form of losing the ability to selectively interaction with the environment; it results in the violation of the sense dynamics and leads to the person's focusing on the past (until reminiscing becomes the only subject of con- 
sciousness and takes on a pathologic character) or future (pseudo-future, pseudolife substituting real life) that is the basis for the behavior deformation in present; dominant concentration on the present when the image of the world is indistinct; centration on the present (now) with the deformation of the space (here); and a loss of the meaning of existence in "everyday cyclic everyday time" (M.M. Bakhtin) which does not have a progressive historical course of events.

The most important point is that the deformations of the life space are always accompanied by the change of the subjective time perception (time "slows down", "speeds up", or "stops", or there is the "timelessness of existence") which occurs because of the "loss of the feeling of reality" and "derealization effects" emerge, etc.

Taking all of this into consideration, the mechanism of the temporal neurosis is as follows. Human life space and subjective time are internally connected, and the axiological dimensions of the life world fulfill a system-forming function, unifying consciousness and activity in the external world. When a person sharply changes his or her lifestyle because he or she becomes a part of a closed environment that regulates (deprivates) him her of selective exchanges with his or her environment, there emerges a reasonable threat that a person as an open self-developing system may be destroyed. Thus, the facts found by Ye.V. Nekrasova become clear, namely that the valuable bases of existence are being destroyed first; in this case the life world is no longer perceived as reality - as a space for the implementation of one's forces. Then the meaning depletion of the life world occurs. It is accompanied by the deformations of the feeling of reality of existence.

It is possible to state that in the subjective field of psychology, a topical and extremely ethically weighted problem exists when a person (an open system) is placed in a closed environment. We believe that in the process of solution of this problem, the real nature of psychological difficulties, which a person who is incarcerated experiences, will be found.

\section{References}

Borodina, V. N. (2008). Osobennosti vospriyatiya subyektivnogo vremeni voennosluzhaschimi po prizyvu [Specifics of perception of subjective time by conscripts]. Izvestiya Rossiiskogo gosudarstvennogo pedagogicheskogo universiteta. Aspirantskie tetradi. [Proceedings of the Russian State Pedagogical University. Postgraduate notes], 28(63), 2, 37-45.

Galazhinsky, E. V., Klochko, V. Y. (2011). Kategoriya «otnoshenie» v psikhologii v svete paradigmaljnoi dinamiki nauki [Category of "attitude" in psychology from the standpoint of the paradigmal dynamics of science]. Mir psikhologii [World of Psychology], 4(68), 14-31.

Galazhinsky, E. V., \& Klochko, V. Y. (2012). System anthropological psychology: Methodological foundations. Psychology in Russia: State of the Art, 5, 81-98. doi: 10.11621/pir.2012.0005

Klochko V. Y. (2008). Modern Psychology: Systems Meaning of a Paradigm Shift. Psychology in Russia: State of the Art, 1, 25-40. doi: 10.11621/pir.2008.0002

Klochko, V. Y. (1996). Chelovek kak psikhologicheskaya sistema [Man as a psychological system] Sibirskiyj psikhologicheskiyj zhurnal [Siberian Psychological Journal], 2, 10-13.

Klochko, Yu. V. (2000). Psikhologicheskie osnovaniya rigidnosti socialjnogo povedeniya studentov [Psychological basis of rigidity in social behavior of students]. Fiksirovannye formy povedeniya: Materialy regionalnoi shkoly molodykh uchenykh [Fixed behavior: Proceedings of the Regional School of Young Scientists]. (pp. 85-90). Bijsk: Univ BiGPI Publ. 
Khoroshavina, E. A (1996). Psikhologicheskii analiz trudnostey adaptatsii slushateley vuza [Psychological analysis of difficulties in adapting the university students] Psikhopedagogika $v$ pravookhranitelnykh organakh [Psychopedagogy in law enforcement], 1, 52-55.

Khudyakova, I. S. (2011). Vliyanie zakrytoy sredy na osobennosti perezhivaniya odinochestva [Effects of closed environment on the particular experience of loneliness] Sbornik nauchnykh trudov: Psikhologicheskie problemy sovremennogo obschestva: opyt resheniya i perspektivy [Collection of scientific works: Psychological problems of modern society: The experience, solutions and perspective] (pp. 97-100). Ekaterinburg: UrGPU Publ.

Krasnoryadtseva, O. M. (1997). Metodologicheskie osnovaniya issledovaniya myshleniya v realjnoi (professionalnoi) deyatelnosti [Methodological bases of the study of thinking in real (professional) activities]. Sibirskiyj psikhologicheskiyj zhurnal [Siberian Psychological Journal], 5, 33-39.

Kravchenko, A. S. (-). Temporalnaya psikhologiya (psikhologiya vremeni). [Temporal Psychology (psychology of time)]. Retrieved from http://www.skravchenko.ru/psychology_time. htm

Nekrasova, E. V. (2001). Metodologicheskie osnovaniya i gipotezy issledovaniya prostranstvenno-vremennoi organizatsii cheloveka [Methodological foundations and hypotheses of the study of the spatio-temporal organization of a man]. Vestnik Altaiskoyi gosudarstvennoi pedagogicheskoi akademii [Bulletin of the Altai State Pedagogical Academy], 1, 9-14.

Pisarev, O.M (2009). Osobennosti kriminalnykh ustanovok v usloviyakh penitentsiarnogo stressa [Specifics of criminal attitudes in prisoners who experience stress]. Sibirskiyj psikhologicheskiyj zhurnal [Siberian Psychological Journal], 31, 36-40.

Rassudova, L. A (2012). Protsess refleksii u deviantnykh podrostkov [The process of reflection in deviant adolescents]. Sovremennye issledovaniya socialnykh problem [Modern studies of social problems], 7(15). Retrieved from http://sisp.nkras.ru/e-ru/issues/2012/7/rassudova.pdf

Tikhomirov, O. K. (1992). Zamechaniya retsenzenta na statyu E.A. Klimova «Ob ambiflektornoi prirode psikhicheskogo» [Reviewer's comments on the paper "On ambiflektory mental nature" by E.A. Klimov] Vestn. Mosk un-ta. Ser. 14. Psikhologiya [Moscow University Psychology Bulletin], 1, 51-60.

Zavershneva, E. Yu. (2008). Zapisnye knizhki, zametki, nauchnye dnevniki L.S. Vygotskogo: rezultaty issledovaniya semeynogo arkhiva [Note-books, notes, scientific diaries of L.S. Vygotsky: results of studying the family archive]. Voprosy psikhologii [Issues in Psychology], 2, 120-135. 